\title{
Casting of AA 7075 Aluminium Alloy into Gravity Die and Effect of the Die Preheating Temperature on Microstructure and Mechanical Properties
}

\author{
Hakan GÖKMEŞE*, Şaban BÜLBÜL, Onur GÖK
}

\begin{abstract}
In this study, light alloy casting technology, which has an important part in gravity die casting applications, was investigated. For this purpose, casting tests were conducted after the modelling and analysis studies of metal tensile bar die at $100^{\circ} \mathrm{C}-150^{\circ} \mathrm{C}-200^{\circ} \mathrm{C}$ preheating temperatures by using finite element analysis method. Casting tests of AA 7075 aluminium alloy into gravity die were carried out at $800^{\circ} \mathrm{C}$ and under different die preheating temperatures. After the casting process, tensile test measurements and hardness measurements of the test samples were made by preparing the tensile bars. Hardness measurements were performed before and after aging heat treatment $\left(120^{\circ} \mathrm{C}-1440\right.$ minutes) as both macrohardness and microhardness. SEM and EDS analyses were performed for the microstructure and fracture surface examinations of the test samples. It was determined with modelling and analysis studies that increasing die preheating temperature increased the thermal stress and deformation and the highest percent elongation was $4.85 \%$ in terms of tensile properties. The hardness value before and after the aging heat treatment showed a decreasing tendency depending on increasing die preheating temperature.
\end{abstract}

Keywords: aluminium, analysis; casting; gravity die casting; mechanical properties

\section{INTRODUCTION}

Nowadays, aluminium and aluminium alloys have become one of the most widely used metal materials in our lives with the rapid advancement of technology and their usage is becoming more widespread. Therefore, aluminium and its alloys are of a great importance in terms of technology. Aluminium found in the rate of approximately $8 \%$ on earth is present in compounds with other metals. Aluminium and aluminium alloys, which started to be used in the industrial area since the middle of the 19th century, are used in today's industry more than the total of other non-ferrous metals such as lead, copper and copper alloys, zinc and tin [1].

Aluminium alloys, which are mostly preferred in applications along with pure aluminium, are very attractive due to their low density, hardening with precipitation, good corrosion resistance, high thermal and electrical conductivity and high damping capacity [2].

$7 \mathrm{xxx}$ alloys are widely used in aerospace, automotive, sporting materials and other fields, due to their high mechanical properties, high strength and hardness, good corrosion resistance and excellent weldability properties among other aluminium alloys [3]. Particularly, by alloying AA 7075 aluminium alloys with zinc, copper and magnesium, high hardness and strength can be obtained in commercial aluminium alloys [4]. In addition, 7075 aluminium alloys of extremely high strength are used in the production technologies of aircraft parts, gears, shafts and other various commercial airplanes, aerospace vehicles and transportation vehicles [5]. Use of aluminium, especially in the aerospace and automobile industry, has led it to be regarded as a "strategic" metal. In order to meet the increasing demands of the above systems, production of large diameter $\mathrm{Al}-\mathrm{Zn}-\mathrm{Mg}-\mathrm{Cu}$ alloy ingot castings with strength, high ductility and high abrasion resistance, has recently become important [6].

In general, the casting methods for producing the AA 7075 aluminium alloy are simple and economical due to the possibility of using conventional casting equipment without limitation for the size and shape of the components [7].
In addition to the mostly used technology of casting to sand die, gravity die casting technology, which is one of the special casting methods, is mostly placed among the casting process options for aluminium alloys [8]. The manufacturing of gravity dies used for moulding aluminium alloys typically contains a wide range of materials from the Grey cast iron to high-strength tool steels. Among the common failure reasons of gravity dies, thermal fatigue cracks, caused by repeated thermal stresses, can be defined on the die surface. Resistance to thermal fatigue can be increased by die materials with combination of high thermal conductivity, high strength at high temperatures, low thermal expansion coefficient and low elastic modulus. Recent studies have continued to improve the quality of gravity dies used in aluminium casting and to extend their life span. In terms of the die material and its lifespan in typical thermal conditions, grey cast iron, ductile iron, casting and forged 4140 type steels or H13 type steels are preferred [9]. In general, in manufacturing with casting technology, the tensile test rods can be produced separately from the casting process (sand or gravity die) in order to evaluate the quality of molten liquid metal [8].

The ASTM B108 standard die design is widely used for industrial casting test rod samples. Besides that, this die design is applicable to gravity die casting technology due to gravity. Demand for use of the gravity die technology is increasing in recent years [10]. Programs, such as casting modelling and analysis, are very important in terms of fault-free casting applications with a design in computer environment without the need of unnecessary and incorrect casting production via trial and error method. Controlling the casting conditions, such as casting temperature of the alloy, the filling time of the liquid metal into the die etc., are also among the important parameters in casting applications [11]. Over the last two decades, optimization of casting processes in terms of their design and quality has considerably increased in parallel with the use of the casting design modelling and analysis software. Today, in many foundries, the production design, modelling and analysis of castings are done in computer environment and the error rate is minimized [12]. 
In this study, gravity die casting technology, mostly found in casting of Al alloys, was in focus. Thus, the gravity die design, focused on production of tensile test rod, thermal stress and deformation analyses were conducted. Then, the microstructure and mechanical properties were investigated before and after the aging heat treatment following the melting and casting processes of AA 7075 aluminium alloy by manufacturing the gravity die.

\section{EXPERIMENTAL}

Fig. 1 shows the process flow chart in this study conducted on the casting of AA7075 aluminium alloy after design, analysis and production of the gravity die. In this study, conducted for this purpose, primarily gravity die design, shown in Fig. 1, was realized. This die is designed to produce a single tensile bar, unlike the die known as ASTM B108 [13]. Effect of the preheating parameter, which has an important influence in gravity die casting applications on the thermal stress and die deformation and metallurgical properties on the die designed in virtual environment, was investigated. Thus, the casting experiments were carried out under $800{ }^{\circ} \mathrm{C}$ casting temperature and 100, 150 and $200{ }^{\circ} \mathrm{C}$ gravity die preheating conditions. Fig. 1 shows the casting test piece and tensile bar obtained as a result of solidification of AA 7075 aluminium alloy after application of the designed and produced gravity die casting.

Chemical composition of AA 7075 aluminium alloy, which was used in gravity die casting experiments, was obtained after the spectral analysis (Tab. 1). It was determined that the result of the spectral analysis confirmed zinc, which is the basic alloying element in AA7075 aluminium alloy.

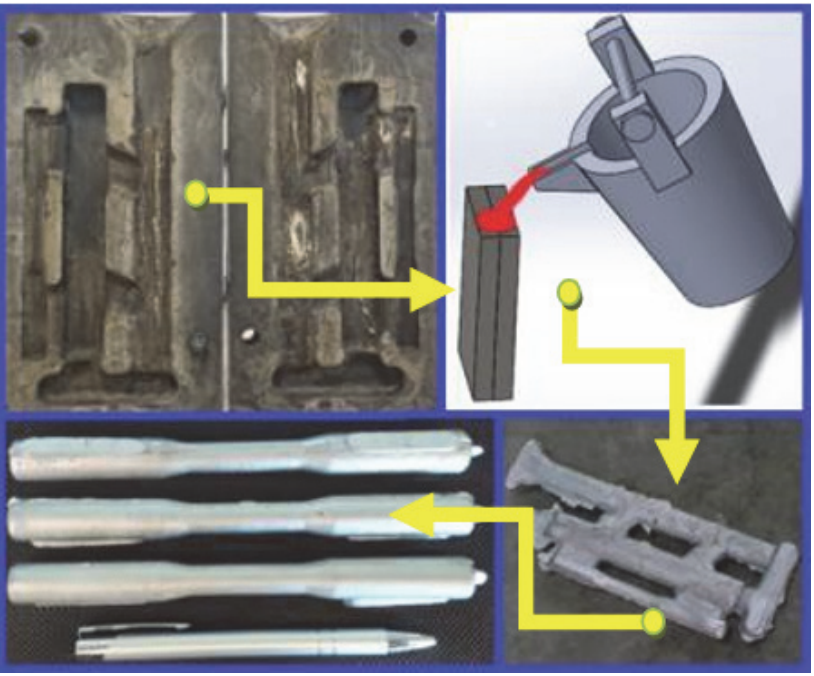

Figure 1 Metallic die design and tensile test samples

Table 1The chemical composition of casting alloys

\begin{tabular}{llllll}
\hline Alloy & $\mathrm{Al}$ & $\mathrm{Si}$ & $\mathrm{Fe}$ & $\mathrm{Cu}$ & $\mathrm{Mn}$ \\
\hline 7075 & 89.10 & 0.37 & 0.38 & 1.70 & 0.17 \\
\hline $\mathrm{Mg}$ & $\mathrm{Zn}$ & $\mathrm{Ni}$ & $\mathrm{Cr}$ & $\mathrm{Ti}$ & $\mathrm{Zr}$ \\
\hline 2.56 & 5.40 & 0.01 & 0.16 & 0.02 & 0.0 \\
\hline
\end{tabular}

After the casting tests, the standard tensile bars of the AA 7075 aluminium alloy, shown in Fig. 1, were obtained. Standard tensile bars were prepared according to the tensile bar dimensions shown in Tab. 2 and Fig. 2 and made ready for the tensile testing. After casting experiments conducted at $800{ }^{\circ} \mathrm{C}$, the test samples were prepared in order to determine the effect of different die preheating temperatures on the microstructure and hardness of the material. Additionally, the effect of aging heat treatment on the mechanical properties of the material in the samples, obtained after the casting experiments, was investigated.

\begin{tabular}{cccc}
\hline \multicolumn{3}{c}{ Table 2 Dimensions of tensile test bar } \\
\hline $\begin{array}{c}\text { Test piece } \\
\text { diameter } \\
\text { do }(\mathrm{mm})\end{array}$ & $\begin{array}{c}\text { Diameter of } \\
\text { the tip } \\
\mathrm{d} 1(\mathrm{~mm})\end{array}$ & $\begin{array}{c}\text { Length } \\
\text { of the tip } \\
\mathrm{h}(\mathrm{mm})\end{array}$ & $\begin{array}{c}\text { First } \\
\text { measurement } \\
\text { length } \\
\text { Lo }(\mathrm{mm})\end{array}$ \\
\hline 10 & M18x2.5 & 25 & 50 \\
\hline $\begin{array}{c}\text { Length of } \\
\text { thinned part } \\
\text { Lc }(\mathrm{mm})\end{array}$ & $\begin{array}{c}\text { Total } \\
\text { length } \\
\text { Lt }(\mathrm{mm})\end{array}$ & $\begin{array}{c}\text { Curve } \\
\text { Radius } \\
\mathrm{R} \text { min }\end{array}$ \\
\hline 60 & 110 & 10 \\
\hline
\end{tabular}

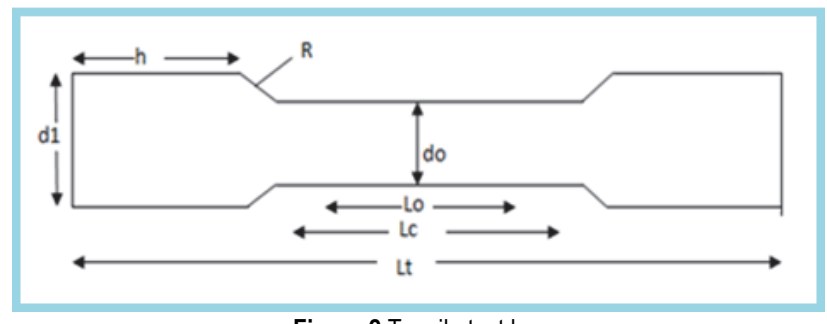

Figure 2 Tensile test bar

Aging heat treatment tests were applied in AA7075 aluminium alloy, as shown in Fig. 3.

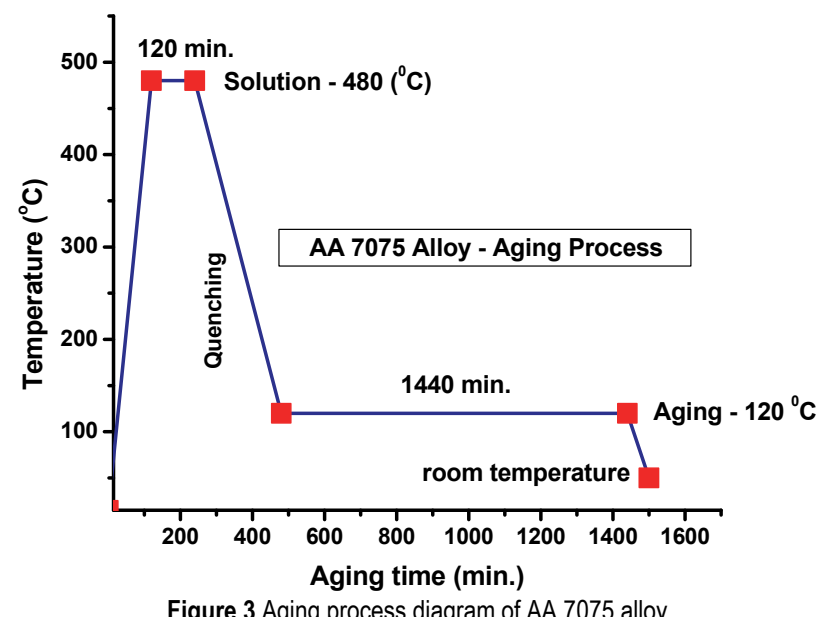

General metallography studies were carried out to determine microstructure in test samples before and after the aging heat treatment. For this purpose, the test samples were subjected to sanding (600-800-1200 $\mu \mathrm{m} \mathrm{SiC}$ abrasive), polishing ( $1 \mu \mathrm{m}$ diamond solution) and etching $0.5 \mathrm{HF}-1.5 \mathrm{HCl}-2.5 \mathrm{HNO}_{3}-95.5 \quad \mathrm{H}_{2} \mathrm{O}$, keller solution) processes, respectively. Hardway brand metallurgical optical microscope was used for microstructure analysis of test specimens cast under different preheating parameters. Hardway brand microhardness (HV 0.1) and 
macrohardness (HRC $60 \mathrm{kgF}$ ) devices were used for hardness measurements before and after the aging heat treatment. Tensile tests of casting AA 7075 aluminium alloy in different preheating temperatures were carried out according to the TS EN ISO 6892-1 standards in DARTEC brand M9000 model $600 \mathrm{kN}$ Universal Tester. After the tensile tests, Scanning Electron Microscopy (SEM) and the related Energy Dispersive Spectrometer (EDS) analyses were used in experimental studies in order to determine the fracture surface morphologies exhibited by the test samples.

\section{RESULTS AND DISCUSSION}

CAD modelling studies of AA 7075 aluminium alloy were conducted before the gravity die casting experiments. Fig. 4 shows the image of the metallic die design as a result of the modelling studies. Mass properties of the casting die were determined, to be used in the modelling and analysis studies before the casting experiments. Tab. 3 shows properties of the determined casting die. In applications of the gravity die casting technology, preheating of the die is an important parameter in order for the liquid metal to fill the die more efficiently and effectively before the casting process after the melting process [10].

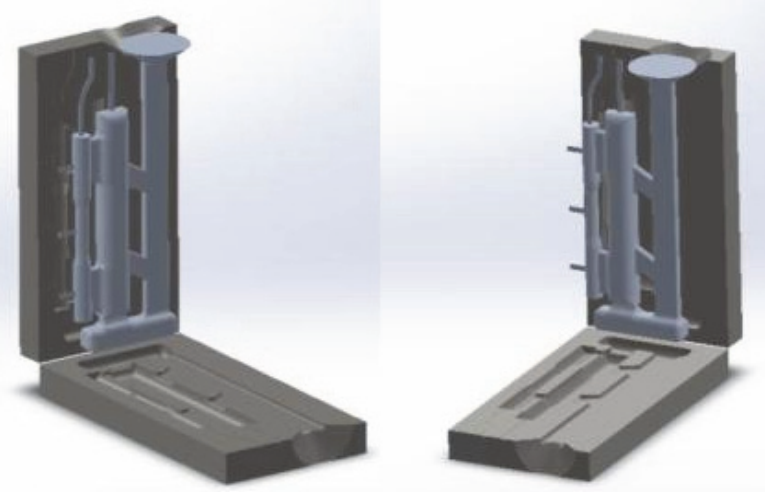

Figure 4. Metallic die design

In this respect, Fig. 5 shows finite element analysis studies conducted after the die design and modelling at 800 ${ }^{\circ} \mathrm{C}$ casting temperature, 100,150 and $200{ }^{\circ} \mathrm{C}$ preheating temperatures. As seen on the die in Fig. 5, the thermal stress distributions on the gravity die surface, depending on the preheating parameter of the die, were evaluated in terms of four regions.

Table 3 Mass properties of casting die

\begin{tabular}{ccc}
\hline Alloy type & $\begin{array}{c}\text { Thermal } \\
\text { conductivity } \\
\mathrm{W} /(\mathrm{m} . \mathrm{K})\end{array}$ & $\begin{array}{c}\text { Specific } \\
\text { heat } \\
\mathrm{J} /(\mathrm{kg} . \mathrm{K})\end{array}$ \\
\hline 7075 & 24.3 & 460 \\
\hline $\begin{array}{c}\text { Mass } \\
\text { density } \\
\mathrm{kg} / \mathrm{m}^{3}\end{array}$ & $\begin{array}{c}\text { Casting } \\
\text { Temperature } \\
{ }^{\circ} \mathrm{C}\end{array}$ & $\begin{array}{c}\text { Die } \\
\text { material }\end{array}$ \\
\hline 7800 & 800 & $\mathrm{H} 13$ \\
\hline
\end{tabular}

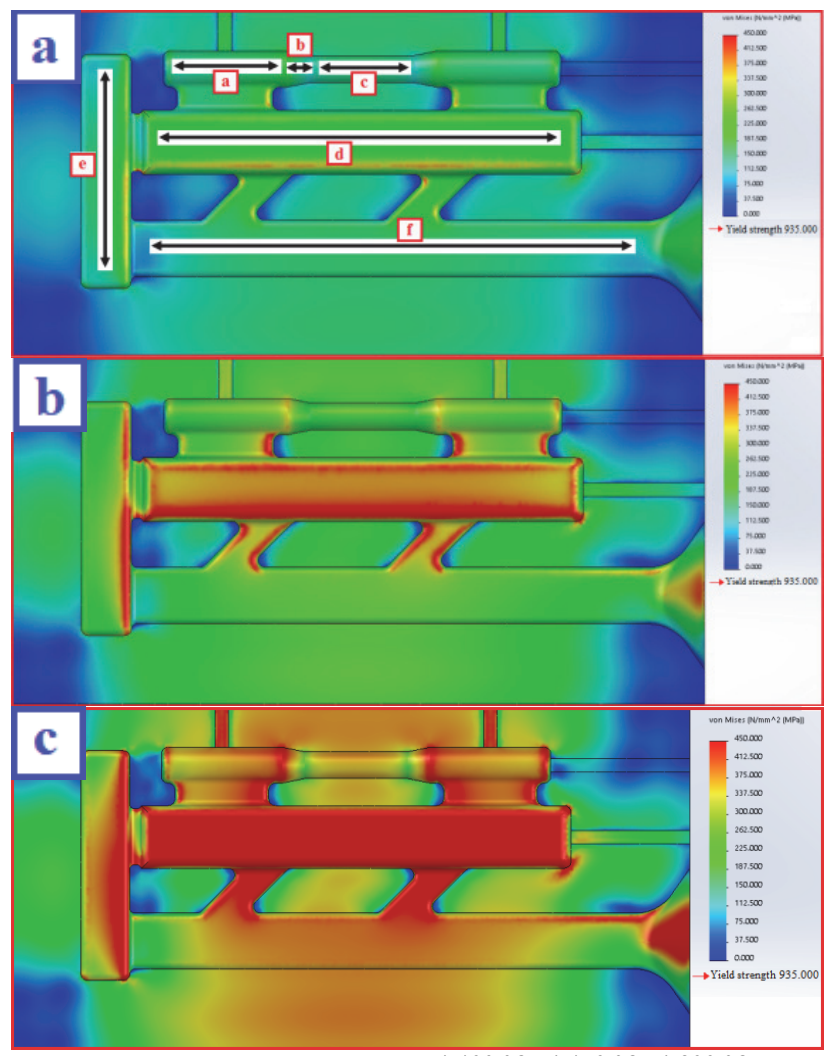

Figure 5 Thermal stress analysis; a) $100^{\circ} \mathrm{C}$; b) $150{ }^{\circ} \mathrm{C}$; c) $200^{\circ} \mathrm{C}$

In this case, depending on the increasing die preheating temperature, thermal stress and deformation are seen to intensify especially in the radius connections on the transition to tensile bar ( $a, b$ and c zone), in the feeder (d zone) with horizontal (e zone) and vertical (f zone) gutter connections. It was thought that the thermal stress and deformation intensified under increasing preheating temperature $\left(200{ }^{\circ} \mathrm{C}\right)$ and this would negatively affect the die service life. Processes of casting the liquid AA 7075 aluminium alloy into the preheated gravity die, at different temperatures $\left(100,150\right.$ and $\left.200{ }^{\circ} \mathrm{C}\right)$, were carried out at $800{ }^{\circ} \mathrm{C}$ and Fig. 6 shows the microstructure images after the solidification.

When the microstructure images given in Fig. 6 were examined, it was observed that the grain size of the sample obtained from the die preheated at $100^{\circ} \mathrm{C}$ was relatively smaller than the other samples. It is known that particle sizes may vary depending on the cooling rate of the liquid metal [14].

It was observed that increase of the die preheating temperature increased the solidification time of the metal cast into the die (reduced the cooling rate of the die) and accordingly the samples had a coarse-grained internal structure. This increase in the preheating temperature did not only cause the grain growth, but also triggered formation of regions prone to segregation with increased diffusion to grain boundaries in the elements such as $\mathrm{Mg}$, $\mathrm{Zn}$, with low melting temperature, in the alloy. This was more apparent on fractured surfaces. Figs. 7, 8, and 9 show the SEM images of the fracture surfaces of the sample obtained with tensile test applied after the casting for the tensile bars of AA 7075 aluminium alloy cast under different preheating temperatures. When the SEM images in Fig. 7 were examined, the brittle fracture morphology 
was found mostly in the microstructure in the tensile bar cast under die preheating temperature applied at $100^{\circ} \mathrm{C}$.

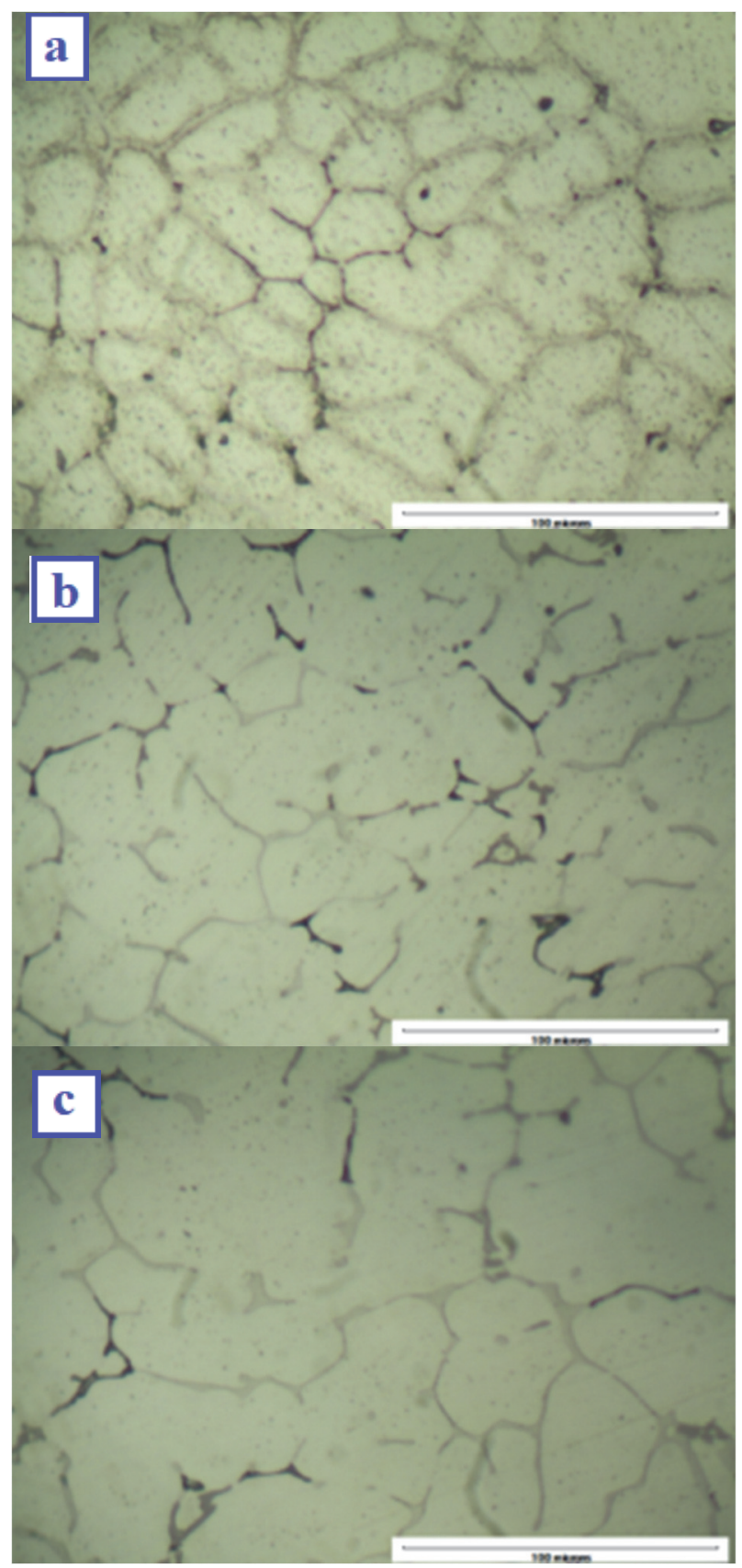

Figure 6 AA 7075 alloy microstructure images cast at different preheating temperatures: a) $100{ }^{\circ} \mathrm{C}$; b) $150{ }^{\circ} \mathrm{C}$; c) $200{ }^{\circ} \mathrm{C}$

The fractured surface forms are very evident since this brittle fracture form [15] occurs as the separation of the grain boundaries depending on the alloying elements in the grain boundaries. In particular, it was found that the brittle fracture morphology seen in Fig. 7 was replaced by ductile fracture morphologies due to increased die preheating temperature $\left(150{ }^{\circ} \mathrm{C}\right.$ and $200{ }^{\circ} \mathrm{C}$ ) (Figs. 8 and 9 respectively). This ductile rupture form can be stated as an increase in grain size at grain boundaries.

Dendritic cells and interdendritic porosity [16] can be observed (Fig. 9b). Depending on the increasing grain size, it can be seen that the breakage in larger islets was in a gradually ductile form. However, it was observed that the intragranular fractures were in brittle form in the inner regions due to segregation and the rupture occurred in plate forms. This trend is clearly observed in Fig. 9c. The fracture forms on the broken surfaces support especially the tensile results in mechanical properties. This was considered as the delayed solidification time under the effect of the increasing preheating temperature. As a type of ductile fracture, it can be stated that large holes were present in the fracture surface morphologies of the sample cast at the preheating temperature of $200{ }^{\circ} \mathrm{C}$. Contrary to this situation, it can be stated that there were traces of brittle fracture morphology in the preheating temperatures of $100{ }^{\circ} \mathrm{C}$ and $150{ }^{\circ} \mathrm{C}$, with the micro-pull and porosity effects, especially around the grain boundaries and around the spherical grains.

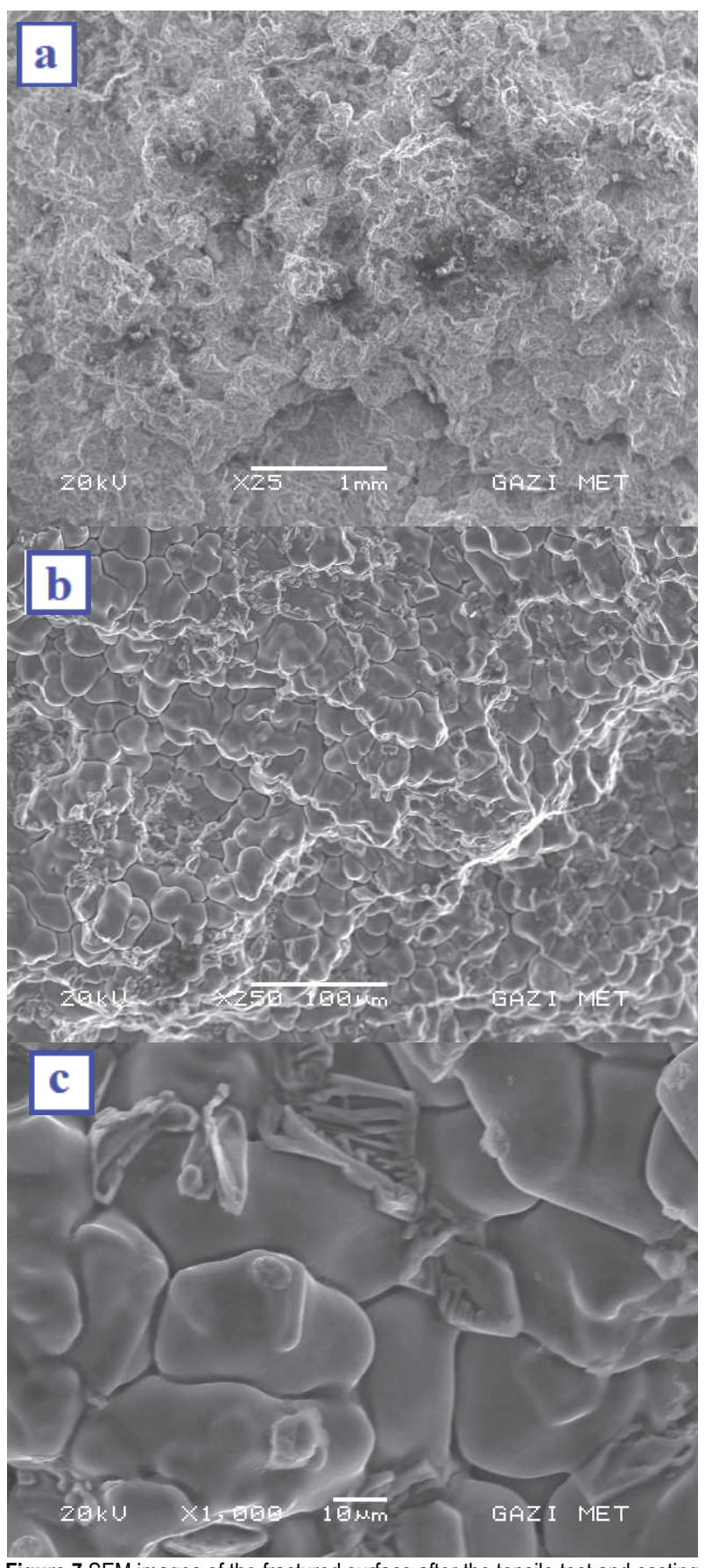

Figure 7 SEM images of the fractured surface after the tensile test and casting with $100{ }^{\circ} \mathrm{C}$ preheating

The EDS analysis was performed in order to determine the fracture surface morphology of the tensile test sample, 
depending on the tensile test after the casting experiments performed under different preheating temperatures (Figs. 10,11 and 12).

Two different points, including especially the flat surfaces on the fracture, surface morphologies (Figs. 10, 11 and $12 \mathrm{a}$ ) of the tensile test samples and the regions showing elevations where regional differences were seen in the fracture were realized (Figs. 10, 11, 12b and 12c). In addition, results of overall distribution analysis of the material were applied as the $3^{\text {rd }}$ analysis (Figs. 10, 11 and 12d). Although the EDS analysis gives elemental results, differentiation of distribution and the formed fracture surface forms can give important results for having an idea related to this differentiation.

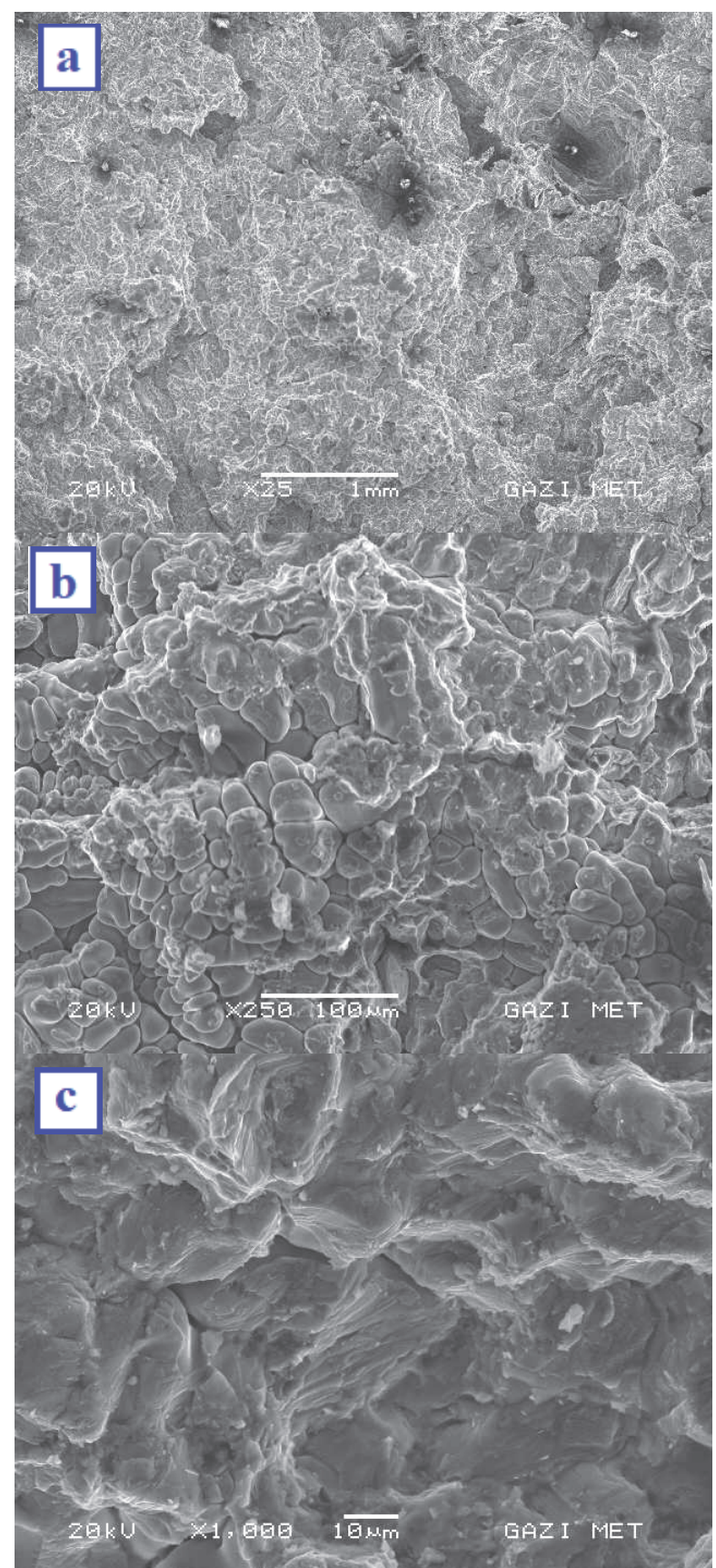

Figure 8 SEM images of the fracture surfaces after the casting and tensile test with $150{ }^{\circ} \mathrm{C}$ preheating

The EDS analyses were compared over $\mathrm{Al}, \mathrm{Zn}, \mathrm{Cu}, \mathrm{Mg}$ and $\mathrm{Fe}$ alloy elements found in the chemical composition of AA 7075 aluminium alloy. According to the $1^{\text {st }}$ and $2^{\text {nd }}$ point EDS analysis of SEM image, showing ductile fracture at increasing die preheating temperature $\left(200^{\circ} \mathrm{C}\right)$ (Figs. 12b and 12c), Zn and Mg basic alloy elements were found to be intense in percentage. A similar situation was also found after the general EDS analysis of a sample in terms of alloy elements (Fig. 12d). When all the EDS results were examined, the main difference was that the presence of micro or macro level segregation zones in the structure, depending on the increasing die preheating temperatures, played a determinant role both in the formation of grain boundaries and in the fracture surface results. Large deep dimples [17] can be seen throughout the surface with broken particles in EDS analysis images. The tensile properties of the metal tensile bars, obtained as a result of the casting experiments of AA 7075 aluminium alloy depending on different die preheating temperatures, are given in Fig. 13, respectively.

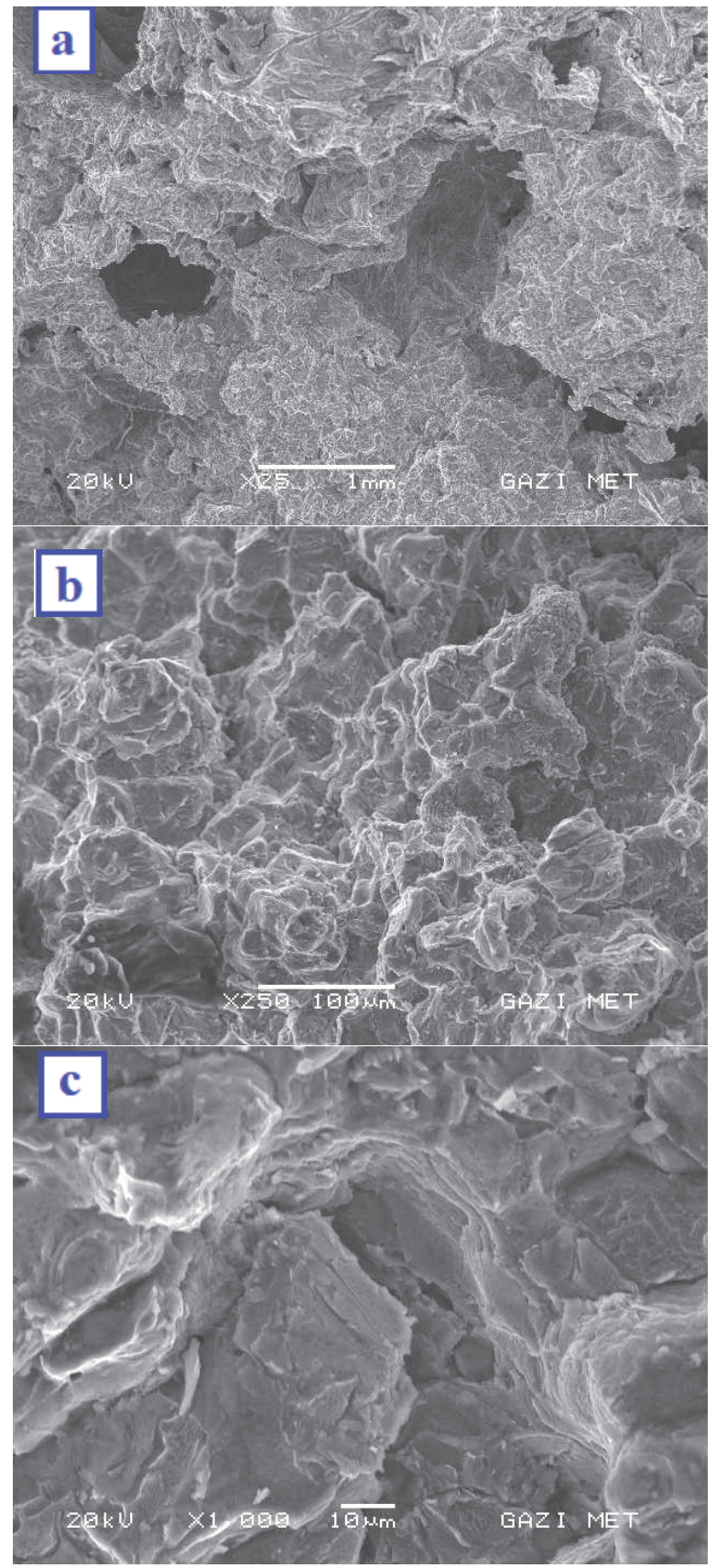

Figure 9 SEM images of the fracture surface after casting and tensile test with $200{ }^{\circ} \mathrm{C}$ preheating 
It was observed that there was an increase in the tensile strength and the \% elongation amount of samples obtained as a result of an increase of the die preheating temperature. According to data obtained from the tensile test results, the highest tensile strength $(164 \mathrm{MPa})$ and the \% elongation amount $(4.85 \%)$ were obtained from the sample cast into the die subjected to preheating less temperature than 200 ${ }^{\circ} \mathrm{C}$ (Fig. 13c). Preheating was applied at $100^{\circ} \mathrm{C}$ and $150{ }^{\circ} \mathrm{C}$ and tensile strength and \% elongation values were determined as $112-137 \mathrm{MPa}$ and $2.40-3.35 \%$, respectively, after the casting. Figs. 14a and 14b show microhardness and macrohardness measurements exhibited by AA7075 aluminium alloy depending on different die preheating temperatures as a result of the casting tests.

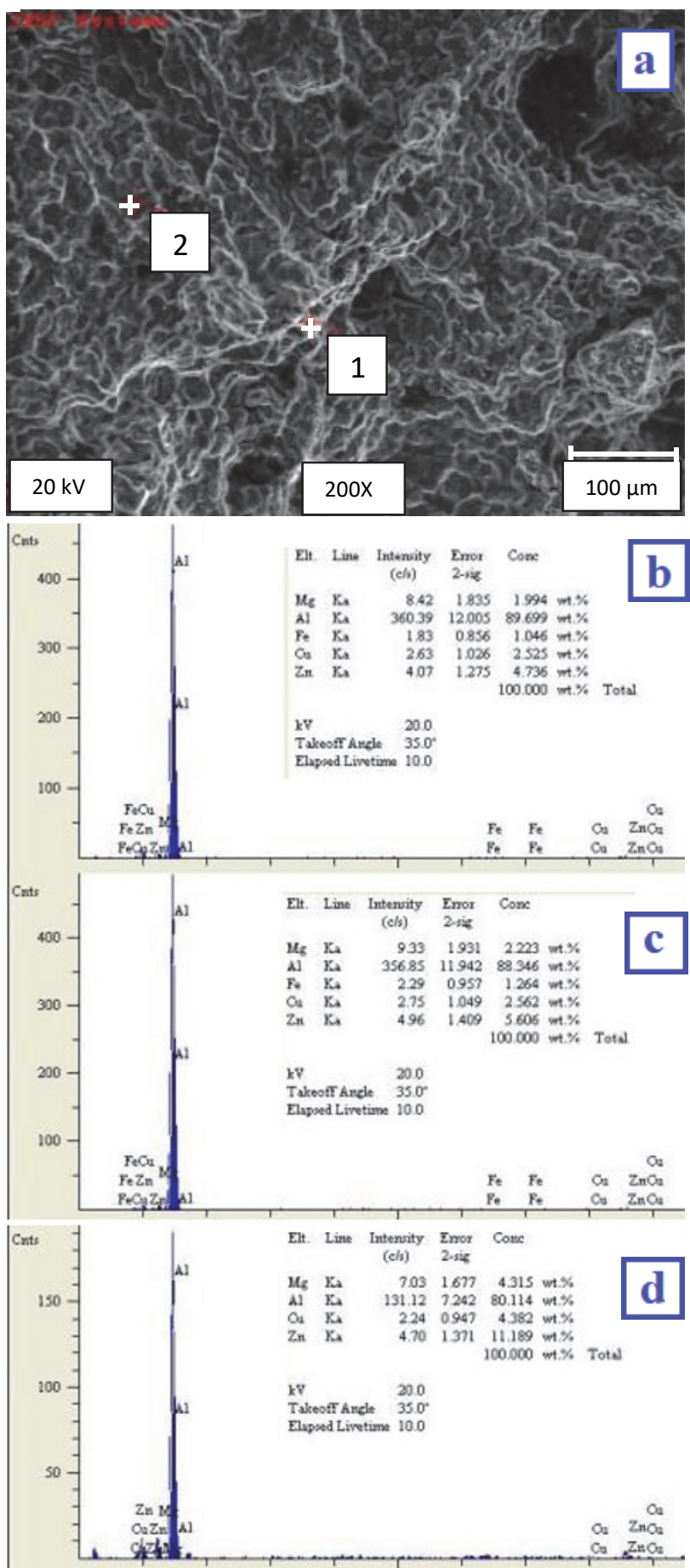

Figure 10 Fracture surface EDS analysis after the casting and tensile test with $100{ }^{\circ} \mathrm{C}$ preheating
When microhardness and macrohardness values of AA 7075 aluminium alloy in Fig. 14 were examined, the hardness values of the material were found to increase significantly depending on the heat treatment performed for 1440 minutes at $120{ }^{\circ} \mathrm{C}$ after 120 minute dissolution at $480{ }^{\circ} \mathrm{C}$ (Fig. 14). The average microhardness values obtained before the aging heat treatment in Fig. 14 were determined as $129.53,126.96$ and $109.3 \mathrm{HV}$, respectively, depending on the die preheating temperatures of 100,150 , and $200^{\circ} \mathrm{C}$.

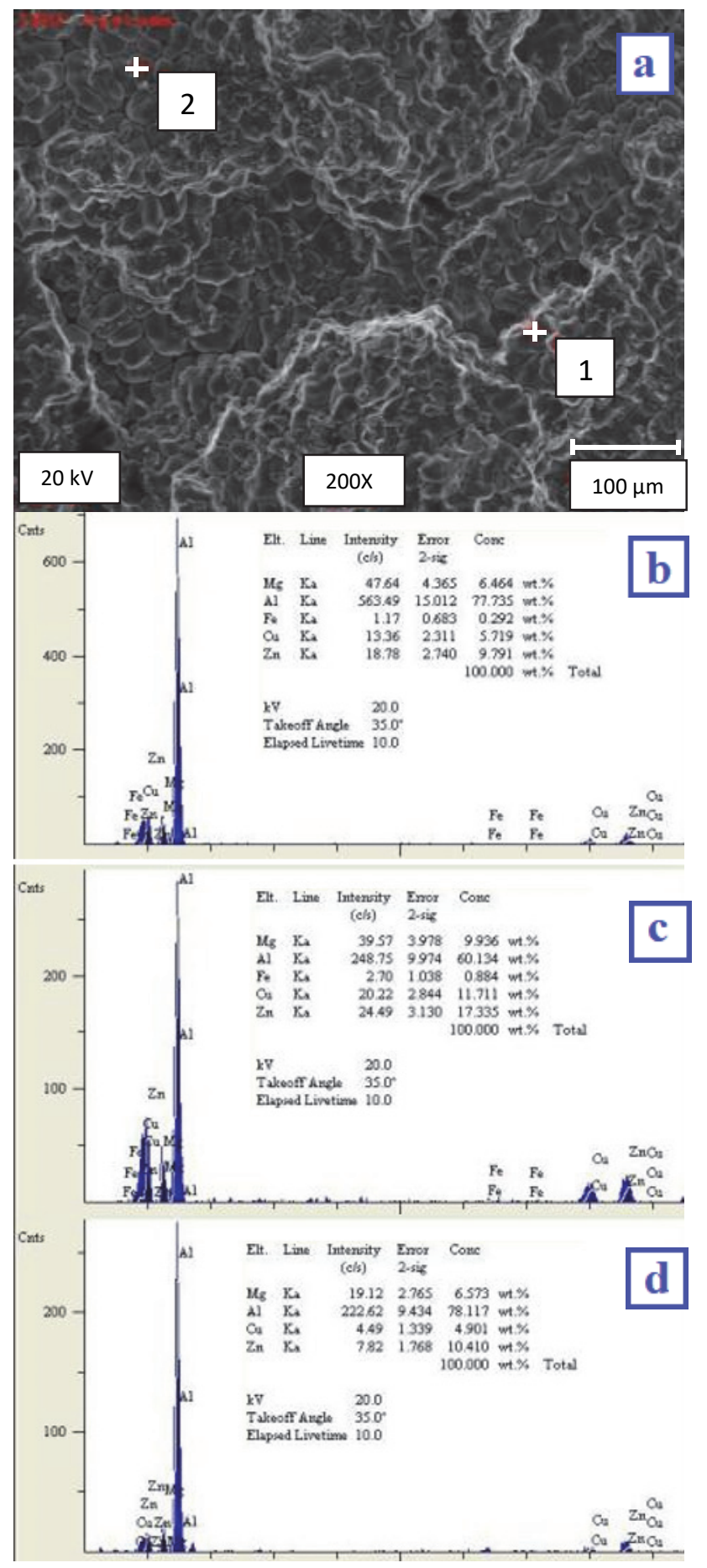

Figure 11 Fracture surface EDS analysis after the casting and tensile test with $150{ }^{\circ} \mathrm{C}$ preheating

The average macrohardness values obtained before the aging heat treatment in Fig. 14b were determined as 86.36, 
81.33, and 72.93 HRB, respectively depending on the die preheating temperatures of 100,150 and $200^{\circ} \mathrm{C}$.

However, after the aging heat treatment processes, both the macrohardness and microhardness values were determined to increase due to all the preheating temperatures. Therefore, the highest hardness value was obtained in the test samples cast under the effect of $100^{\circ} \mathrm{C}$ die preheating temperature. Thus, microhardness and macrohardness values after the aging treatment were measured as $152.16 \mathrm{HV}$ and $110.77 \mathrm{HRB}$, respectively.

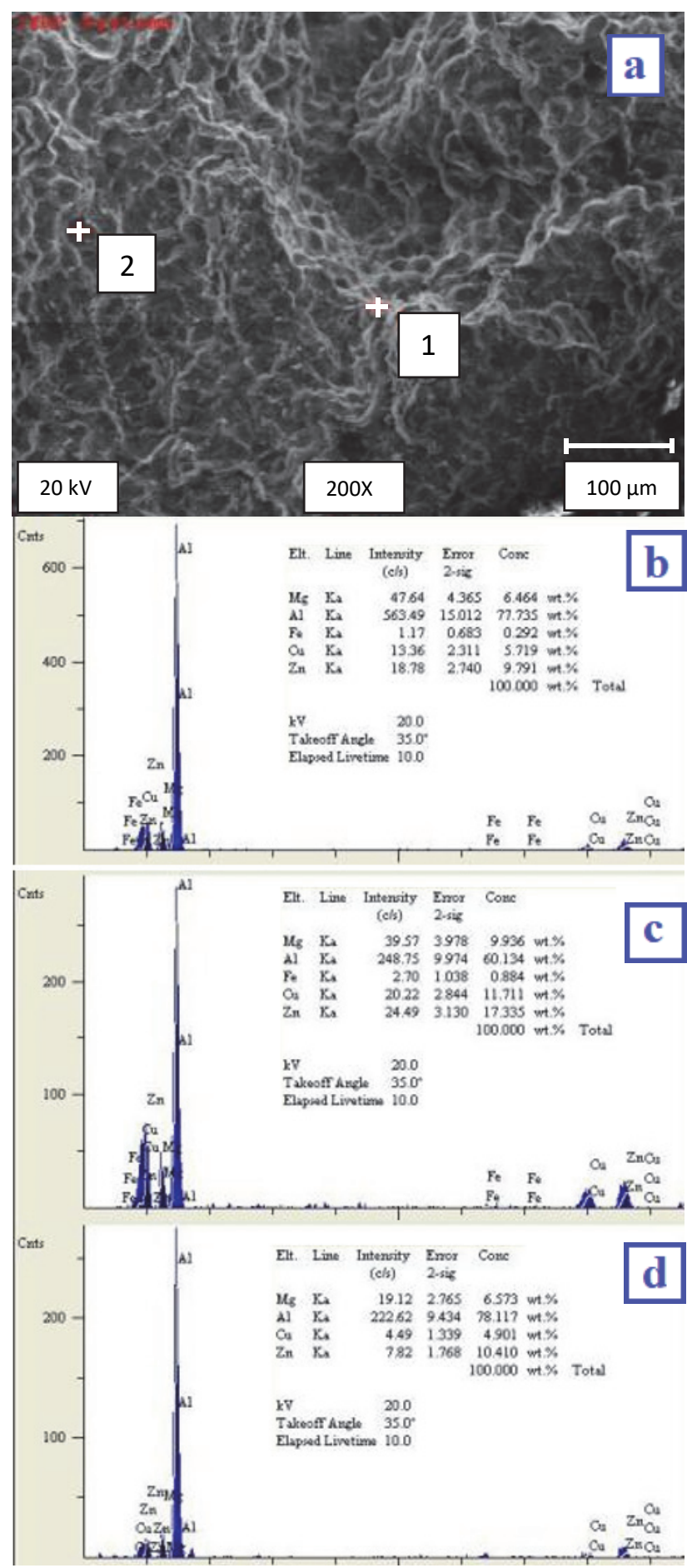

Figure 12 Fracture surface EDS analysis after the casting and tensile test with $20{ }^{\circ} \mathrm{C}$ preheating

This increased the microhardness values by $17.8 \%$ and the macrohardness values by $27.9 \%$ compared to the test samples before the aging heat treatment after casting. This clearly showed the effect of the die preheating temperature or the aging heat treatment after casting tests on the microstructure and mechanical properties of the material especially in industrial applications.

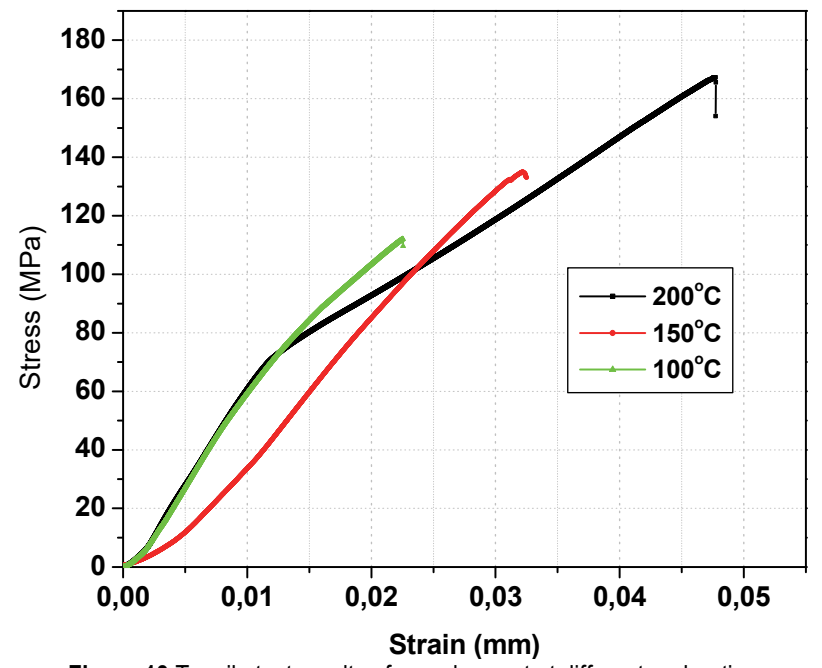

Figure 13 Tensile test results of samples cast at different preheating temperatures

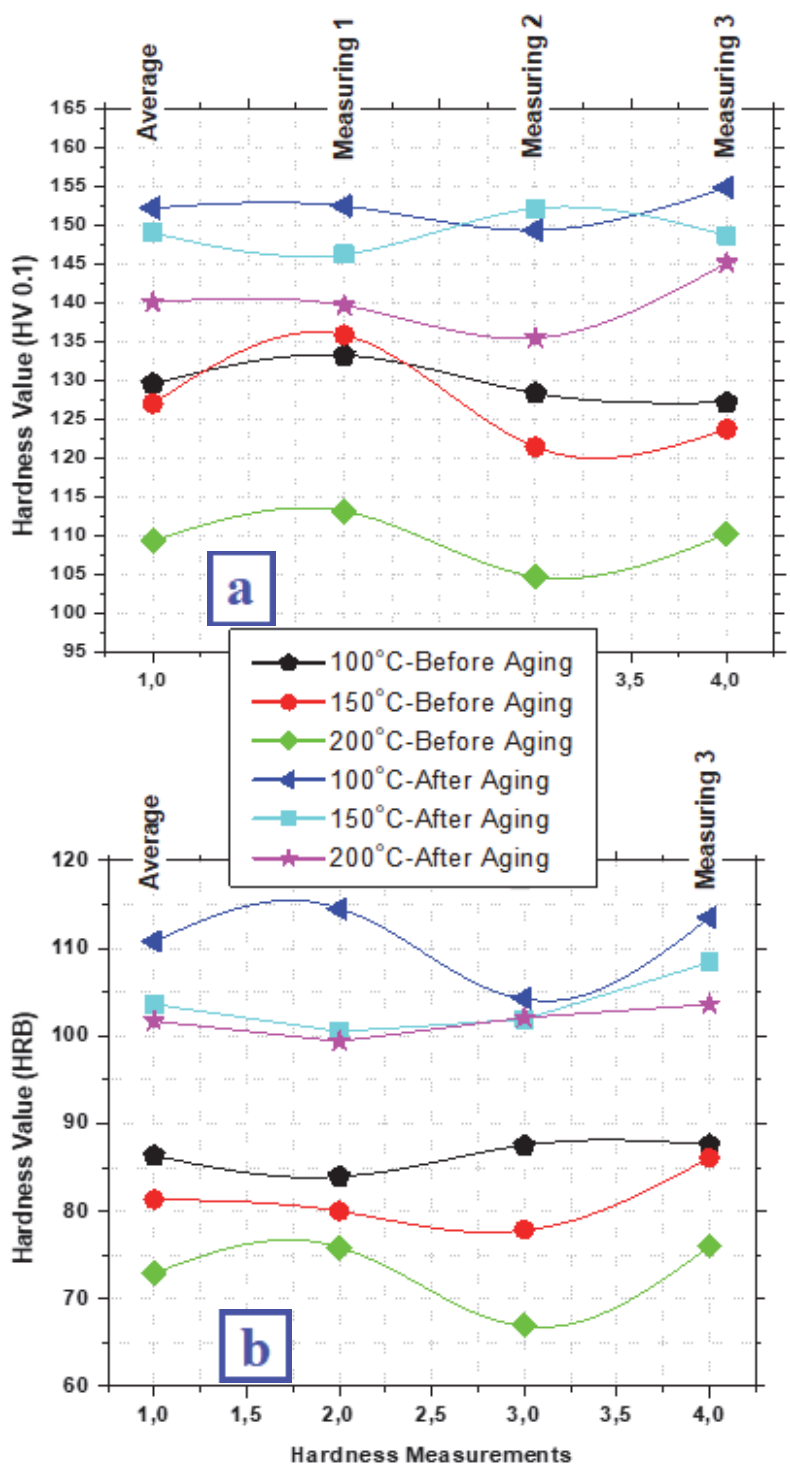

Figure 14 The hardness results of the samples cast at different preheating temperatures: a) Microhardness; b) Macrohardness 


\section{CONCLUSIONS}

The experimental results obtained as a result of the gravity die casting tests under different die preheating temperatures and the casting die modelling of AA 7075 aluminium alloy are summarised below.

It was determined, because of the gravity die CAD modelling studies, that the increased die preheating temperature exhibited a negative effect in terms of thermal stress, deformation and die life. Casting microstructure in the increasing die preheating temperature coarsened in terms of grain size. After tensile test was determined that the brittle fracture behaviour of the fracture surface morphologies was replaced by ductile behaviour at grain boundaries depending on the increasing die preheating temperature, but separations occurred in brittle grains depending on segregation inside the grains. In addition, there was an increase in the tensile elongation values of the sample and it was found as $4.85 \%$ in $200{ }^{\circ} \mathrm{C}$ die preheating temperature. Microhardness and macrohardness values after the applied aging heat treatment process were obtained as $152.16 \mathrm{HV}$ and $110.77 \mathrm{HRB}$ from the test samples cast in the die preheating process at $100{ }^{\circ} \mathrm{C}$. When the stated results are examined, die preheating temperature can be effective especially in light alloy (Al, $\mathrm{Zn}, \mathrm{Mg}$, etc.) castings. Thus, die forming, die deformation and life, microstructure and mechanical properties can be directly affected in gravity die casting applications.

\section{REFERENCES}

[1] Anand, R. \& Deva, K. (2017). Micro Structure and Mechanical Behavior of AL-7075-T6 and Fly Ash Metal Matrix composite Produced by Stir Casting Process. International Journal of Theoretical and Applied Mechanics, 12(2), 365-374.

[2] Vannan, E. \& Vizhian, P. (2014). Microstructure and Mechanical Properties of as Cast Aluminium Alloy 7075/ Ba salt Dispersed Metal Matrix Composites. Journal of Minerals and Materials Characterization and Engineering, 2, 182-193. https://doi.org/10.4236/jmmce.2014.23023

[3] Chen, X. H., Yan, H., \& Jie, X. P. (2015). Effects of Ti Addition on Microstructure and Mechanical Properties of 7075 Alloy. International Journal of Cast Metals Research, 28(3), 151-157. https://doi.org/10.1179/1743133614Y.0000000137

[4] Kilıçlı, V., Akar, N., Erdoğan, M., \& Kocatepe K. (2016). Tensile Fracture Behavior of AA7075 Alloy Produced by Thixocasting. Trans. Nonferrous Met. Soc. China, 26, 12221231. https://doi.org/10.1016/S1003-6326(16)64223-1

[5] Ezatpour, H. R., Torabi, M. P., Sajjadi, S. A., Ebrahimi, G. R., \& Chaichi, A. (2016). Microstructure, Mechanical Analysis and Optimal Selection Of 7075 Aluminum Alloy Based Composite Reinforced with Alumina Nanoparticles. Materials Chemistry and Physics, 178, 119-127. https://doi.org/10.1016/j.matchemphys.2016.04.078

[6] Mingfan, Q., Yonglin, K., Guoming, Z., Yangde, L., \& Weirong, L. (2017). Improving Microstructure and Mechanical Properties for Large-Diameter 7075 Aluminum Alloy Ingotsby a Forced Convection Stirring Casting Process. Metallurgical and Materials Transactions B, 48B, 993-1003. https://doi.org/10.1007/s11663-016-0884-6

[7] Shaoming, M., Youhong, S., Huiyuan, W., Xiaoshu, L., Ming, Q., Yinlong, M., Chi, Z., \& Baochang, L. (2017). Effect of a Minor Sr Modifier on the Microstructures and
Mechanical Properties of 7075 T6 Al Alloys. Metals, 7(13), 1-11. https://doi.org/10.3390/met7010013

[8] Wang, Y., Neff, D., Schwam, D., Zhu, X., \& Chen, C., (2013). Optimization of Permanent Mold Mechanical Property Test Barsin A356 Alloy Using A New MoldDesing. International Journal of Metalcasting, 26-38. https://doi.org/10.1007/BF03355556

[9] Material and Coating Improvements Target Increased Life Span and Reduced Cost of Permanent Molds. Metal Casting, 2000.

[10] Birsan, G., Ashtari, P., \& Shankar, S. (2011). Valid Mould and Process Design to Cast Tensile and Fatigue Test Bars in Tilt Pour Casting Process. International Journal of Cast Metals Research, 24(6), 378-384. https://doi.org/10.1179/1743133611Y.0000000005

[11] Akar, N., Kayıkc1, R., \& Kısaoğlu, A. K. (2014). Model-ling of critical solid fraction factor depending on mold temperature and grain size of $\mathrm{Al}-4,3 \mathrm{Cu}$ alloy poured in-to permanent mold. Journal of Polytechnic, 17(2), 83-89.

[12] Akar, N., Boran, K., \& Hozikliğil, B. (2013). Effect of mold temperature on heat transfer coefficient at cast-ing-mold interface. Journal of the Faculty of Engineering and Architecture of Gazi University, 28(2), 275-282.

[13] Sigworth, G. K. (2011). Understanding Quality in Aluminum Castings. American Foundry Society, 1-17. https://doi.org/10.1007/BF03355504

[14] Malekan, M., Naghdali, S., Abrishami, S., \& Mirghaderi, S. H. (2016). Effect of cooling rate on the solidification characteristics and dendrite coherency point of ADC12 aluminum die casting alloy using thermal analysis. Journal of Thermal Analysis and Calorimetry, 124(2), 601-609. https://doi.org/10.1007/s10973-015-5232-6

[15] Mohsen, O. S., Amir, B., Ali, K., \& Fatemeh, H. (2020). Evaluation of Fracture Mechanisms in Al-Si Metal Matrix Nanocomposites Produced by Three Methods of Gravity Sand Casting, Squeeze Casting and Compo Casting in SemiSolid State. Silicon, 12, 2977-2987. https://doi.org/10.1007/s12633-020-00390-9

[16] Iryna, H., Stefan, M., \& Lenka, M. (2019). Dependence of Mechanical Properties on Porosity of AlSi7Mg0.3 Alloy During Gravity Casting. Engineering for Rural Development, 1001-1006.

[17] Mohamed, F. I., Guillermo, H. G., Agnes, M. S., \& Fawzy, H. S. (2016). Optimizing the Heat Treatment of HighStrength 7075-Type Wrought Alloys: A Metallographic Study. International Journal of Metalcasting, 10(3), 264275. https://doi.org/10.1007/s40962-016-0038-2

\section{Contact information:}

\section{Hakan GÖKMEŞE}

(Corresponding author)

Necmettin Erbakan University,

Seydişehir Ahmet Cengiz Engineering Faculty, Dept. of Mechanical Eng.,

Seydişehir- Konya, 42370 Turkey

E-mail: hakan1440@gmail.com

\section{Şaban BÜLBÜL}

Necmettin Erbakan University,

Seydişehir Ahmet Cengiz Engineering Faculty, Dept. of Mechanical Eng.,

Seydişehir- Konya, 42370 Turkey

E-mail: sabanbulbul42@hotmail.com

\section{Onur GÖK}

Necmettin Erbakan University,

Seydişehir Vocational School, Department of Machine and Metal Technologies,

Seydişehir- Konya, 42370 Turkey

E-mail: ogok@erbakan.edu.tr 